\title{
Leadership And Decision Making In The Project Management Life Cycle: A Knowledge Management Perspective
}

\author{
Fazaila Shad \\ fazaila.shad@gmail.com \\ Dr. Mehnaz Gul \\ Assistant Professor, Institute of Management Studies \\ University of Peshawar, Pakistan \\ mehnazgul@uop.edu.pk \\ Dr. Muhammad Zahid \\ Assistant Professor City University of Science and IT Peshawar \\ Mianmz11@gmail.com
}

\begin{abstract}
All organisations are adopting the project-based approach to carry out operational and business activities. There are many challenges of knowledge management during the project management life cycle because every project has unique characteristics with a changing workforce. Project management involves the leadership and critical decision making which requires the internal and external experts and knowledge. The study is conducted to find out how knowledge management affects leadership and critical decision making in the project management life cycle. The objective of the study is to explore the role of knowledge management in project management and to evaluate the problems of knowledge management in the project management life cycle. In the project management life cycle, much information is generated and experienced. Thus, the study finds out that if the knowledge is not accumulated and recorded correctly, it will be lost and cannot use in future projects. Leadership and critical decision making are affected by knowledge management. Thus, to ensure the best leadership and better decision making there must be proper knowledge management.
\end{abstract}

Key words: Leadership, Decision Making, Knowledge Mangement

\section{Introduction}

Due to the growing knowledge-intensity of work content,the knowledge economy is of great importance to project-based organisations (Hanisch et al., 2009). Knowledge management defined as the process of developing, capturing, and handling of organisational information (Alavi \& Leidner, 2001).Project management defined as the application of tools, skills and techniques to project activities to fulfill the project requirements (Chapman \& Ward, 1996). The continuous de-materialisation of the value chain has a significant impact on economic development. Knowledge is an intangible asset of every organisation (Nahapiet \&Ghoshal,1998). Knowledge management plays pivotal roles during the project management life cycle. Due to their unique characteristic's projects are different from standard organisational processes (Schindler \& Eppler. 2003). The management of knowledge is an increasingly essential, competitive and decisive factor in an organisation, leadership considered as theessential factor in 
achieving project success. Leadership is an act of leading a group or organisation which requiresspecific skills and knowledge (Ford \& Harding, 2018). The multi-cultural collaboration projects are alwayscritical and required excellent leadership skills during the critical decisionmaking process. Critical decision making in the project requires direction, authority and management skills and behavior (Fewings \&Henjewele, 2019). Leadership is knowledge to set the vision, goals and strategy of the project. Leadership in the project management life cycle is a transfer of crucial direction and information in project management (Muller et al., 2018). All these indicate that knowledge management is the only tool through which leadership and criticaldecision-making take part in the project management life cycle (Cleland, 1995).Knowledge comes from many different sources within project management. Knowledge management activities include the organising, capturing, refining, and exchange of knowledge (Rubenstein et al., 2001). There are many problems in project management due to which knowledge management can be broken down such as lack of time, insufficient knowledge and lack of knowledge sharing and mismanagement (Leseure \& Brookes, 2004). The mismanagement of knowledge in project management leads to project failure. Thus, knowledge management has a significant effect on project leadership and critical decision making, which accomplished through the proper means of knowledge. The study is conducted to find out the challenges of knowledge management in the project life cycle and its impact on project leadership and critical decision making. The study aimed to find out what are the challenges of knowledge management in a project environment.Moreover,how knowledge management affects leadership and critical decision making in the project management life cycle?The objective of the study isto explore the role of knowledge management in project management and to evaluate the problems of knowledge management in the project management life cycle. The study also aims to examine the role of knowledge management in leadership and critical decision making in project management. The qualitative study will be conducted to find out the effect of knowledge management on project leadership and critical decision making in the project management life cycle and the problems of knowledge management in the project management life cycle. Semi-structured interviews conducted with project managers and other employees of the department through convenience sampling.

\section{Literature Review}

Todorovic et al. (2015) in his study about the knowledge-based organisation, highlights the challenges of knowledge management in a project environment and also provide a review of concepts that are relevant to project management. The study also provides the project success analysis framework. The impact of knowledge managementimplies that project success is more reliant on knowledge management. However, without knowledge managementis almost impossible to capture, organises and shares the information within team members of the project.Cha $\mathrm{j}$ et al. (2018) in his research study on project management highlights information system projects, and the organisation transformation enabled. The project management body of knowledge has not adequately addressed the problems of knowledge management. The transformational contexts in project management bodies were examined by the study. This conceptual paper focuses too much emphasis on the supply outputs, and the project management body'sknowledgeis limited. The project management framework provided in the study focused on the knowledge to achieve successful organisational transformation.Ramazani \&Jergeas (2015) examined the project management education from the perspective of working managers; there is a gap between education providers anddeal with today's complex environment. The study explores 
that education and training institutions can produce good project managers with leadership capability to lead and work effectively according to project requirements.Decision making and critical thinking are an essential part of any successful project this study formulates the three main ideas including the development of critical thinking, developing interpersonal and leadership skills, and engage the mangers in the context of real-life projects, according to these three ideas the project managers can be trained and ensure the success of the project. Ajmal et al., (2010) in his study, examines the factors responsible for the failure and success of knowledge management in project-based companies and organisation. The study proposed a knowledge initiative model comprises of six factors. The model is examined online by project managers in companies. The study shows that the absence of an appropriate information system, lack of means of sharing and less incentive are the significant reasons forknowledge management failure.

\section{Conceptual framework}

The below conceptual framework the relationship between knowledge management and project management are explained in the context of leadership and critical decision making (see Figure $1)$.

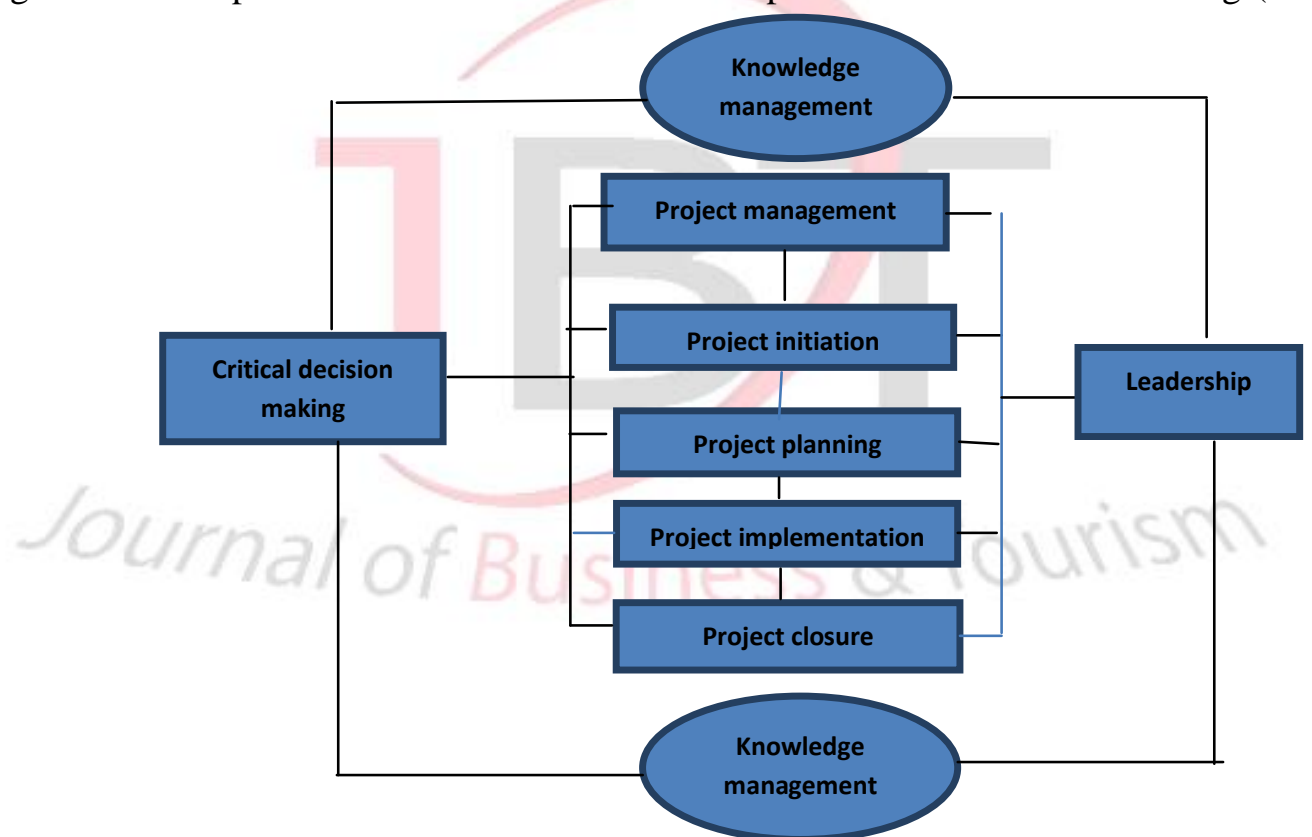

Figure 1: Knowledge Management and Project Management Process

The process of Project management life cycle includes project initiation, project planning, project implementation and project closure. Project management requires the characterised support of the leadership and decision making from planning to the execution of the project.Project decision making supports the planning, leading and controlling of the project. There are many leadership styles in project management with varying degrees of vitality (Politis, 2001). There are concernsabouttasks, concerns of people, and concerns of results faced by the project leader during the life cycle of the project (Srivastava et al., 2006). The leadership behaviors and the project performance at the workplace affect the critical decision making within an organisation (Donate \& Pablo, 2015). Decision making could be possible through knowledge management.Organisations create value from knowledge-based assets (Alavi \& Leidner, 2001). This value involves the sharing of knowledge among employees, capturing the employees and 
other companies and even department to create best practices. Knowledge management becomes a skill of a modern manager because of its central concern (Davenport et al., 1998). Knowledge management is of great importance within the organisation. Project knowledge established by the people involved in the project. Knowledge management plays a vital role during the project management life cycle. Knowledge management helped to form project leaders and helps in critical decision making through knowledge and information (Nicolas, 2004).

\section{Findings and analysis}

Though knowledge management plays a vital role in project management, it has its challenges. The management of knowledge is essential for project success. Most organisations are not able to initiate and evaluate a good project and learn from them. It shouldbe a daily routine to maximise knowledge and capture learning. Knowledge management is a complex task in knowledge-based organisations, because the project team members are of diverse cultures and skills, working together for a specified periodGareis \& Huemann, 2000). Many projects lack knowledge due to which the projects are failing. There must be proper supporting documentation and flow of information within the project management life cycle.Knowledge management plays a vital role in project management. A manager can create knowledge by two means, either reusing the existing knowledge or creating new knowledge. The existing knowledge is used in current situations to learn from past experiences and to perform better within a project while the new knowledge generated for future projects and learning. During project planning there, we can create a map not only for knowledge but for project success all it depends on planning. For planning, we need strong leadership skills and for implementing the plan a robust decision making will, which is not possible without knowledge management (Chapman \& Ward 1996).The challenges in project management depend upon the nature of the project.Successful project knowledge management helps in facilitating project-based organisations and facilitate decision making (Caniëls \& Bakens, 2012).Project success mostly depends on knowledge management. The knowledge of the project management life cycle can be reused in other related projects to reduce the time, cost, efforts and resources to create new outputs (Arora et al., 2010).

Within the organisation, there are some personalisation and codification strategies used for knowledge management. Thechallenges faced by knowledge management are many in numbers. The main problem is the time and constraints because due to lack of time the knowledge management is neglected somehow (Hwang et al., 2013). When the current project has finished the staff and reject team members need to be assigned to another project immediately as soon as the current project closed. So,workingwith the knowledge management in such situations becomes difficult.There are resistances to talk about mistakes in some organisations which may create further challenges for knowledge management in the project management life cycle. Many people resist to talk about mistakes, and that is the normal behavior of most of the employees. Due to the resistance to talk about mistakes results in the lack of analysisand lead to the failure of the project. The problems that occurred duringthe project management life cycle should be noted and analysed for better understanding and future projects so that the time and resources invested should not be wasted (Hwang et al., 2013). There is always a problem of low motivation faced by almost every organisation. The low motivation resists people to transfer the information because the problem with low motivated people is that they do not think of it as their responsibility and do not think of it as a benefit to their work and place (Ferarris, 2019). Employees should be motivated to transfer the knowledge and information to each other only in this way the knowledge management takes place within an organisation. 
The challenge faced by knowledge management within the project management life cycle is the lack of leadership. Sometimes managers may not put emphasis on knowledge and cannot transfer the knowledge due to poor leadership skills. The communication gap created among project team members and the challenge for knowledge management created (Fischer \& Otswald, 2001). There is also a lack of strategy due to which the process of knowledge is disturbing. There is a need fora proper strategy for knowledge management within a project environment.Technology is always required to store knowledge; without technology in this modern world, the initiatives and ideas cannot be operationally secure. Thus, it is required to store and share knowledge. It facilitatesknowledge management within an organisation (Al Saifi, 2019). People may be able to make decisions based on accurate information provided by project employees. It could be possible through the use of proper technology.The lack of shared understanding and cultural differences also affect knowledge within an organisation. People are usually more concerned about the tasks for which they will be evaluated but are not concerned about the retrieving and sharing of knowledge and information seeking. It usually happens when time is limited.There is also a lack of training in project management due to the short period, and project uniqueness every project required different levels of expertise. It becomes difficult to due to lack of training because project done in many areas involving different people required different experiences and skills. Thus, lack of training is the hurdle in the way of managing the knowledge see Table 1 for detail.

Table 1: Themes of the Results

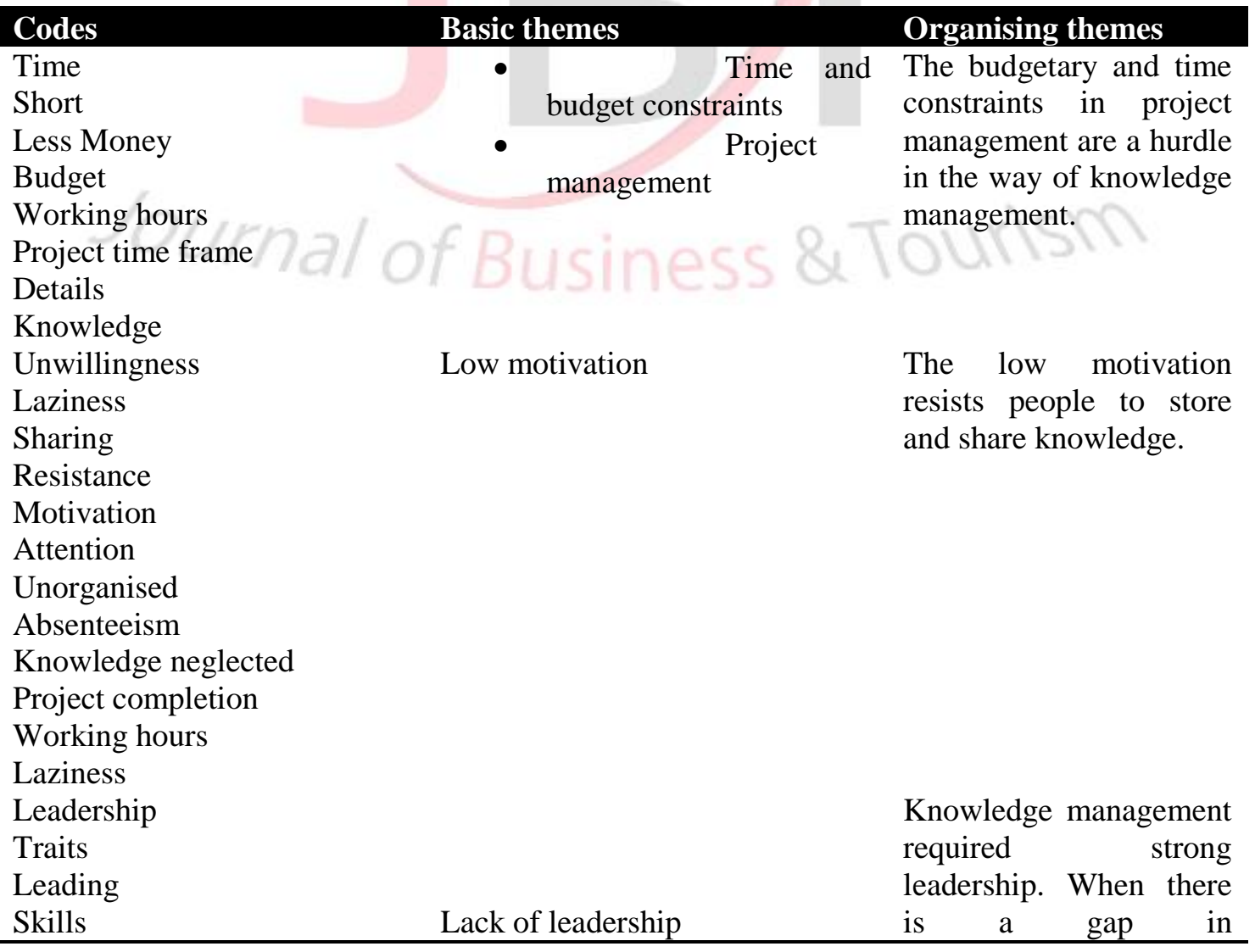




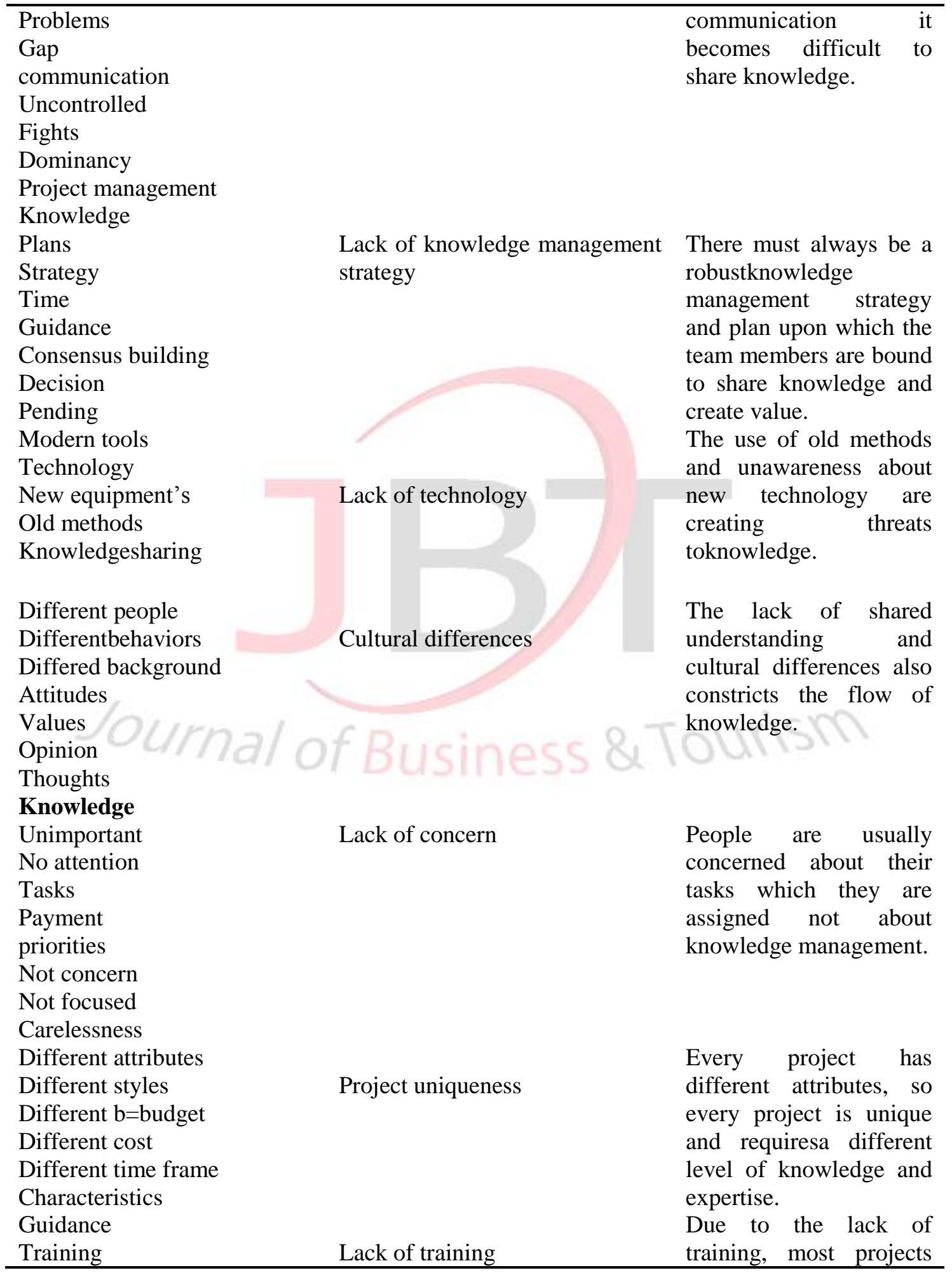




\begin{tabular}{llr}
\hline Programs & fail, & where \\
Knowledge generation & knowledgecannot & be \\
New techniques & transmitted. \\
Camps & & \\
\hline
\end{tabular}

\section{Conclusion}

The paper illustrates the findings of the exploratory study on the knowledge management perspective in the project management life cycle and the importance of knowledge management in the project management life cycle. Knowledge management is the topic of most significant concern in project-based organisations nowadays, but still, the significance of knowledgemanagement in project management is insufficiently used. The technological advancement facilitates the use of the storage of information and knowledge, but it is of no use if employees resistapplying it in practice during working hours.From the paper, it can be concludedthat knowledgemanagement has its difficulties and challenges because in many organisations the knowledge management is not considered an essential asset. Moreover,knowledgemanagement is not part of some organisation cultureswhere employees do not understand the importance of knowledgesharing. Thoughthe lesson learned system and knowledge bases are available to support knowledge documentation and storage. Failure of effective knowledge management means the failure of the project;knowledge management playsan essential role in the success of the project.The project created knowledge falls in the three categories, including technical knowledge, project management knowledge and project-related knowledge. Thus, managing knowledge is very important for project success. Despite many obstacles and hurdles come in the way of successfulknowledge management such as low motivation and lack of leadership, lack of training and project uniqueness. For better leadership and decision making during the project management life cycles, the role of knowledge management cannot be denied. Knowledge management ensures the success of the project.

\section{References}

Arora, P., Owens, D., \& Khazanchi, D. (2010). A pattern-based tool for knowledge management in virtual projects. The IUP Journal of knowledge management, 8(3), 60-64.

Davenport, T. H., De Long, D. W., \& Beers, M. C. (1998). Successful knowledge management projects. Sloan management review, 39(2), 43-57.

Hanisch, Bastian, et al. (2009). Knowledge management in project environments." Journal of knowledge management 13.4 148-160.

Nahapiet, J., \& Ghoshal, S. (1998). Social capital, intellectual capital, and the organizational advantage. Academy of management review, 23(2), 242-266.

Schindler, M., \& Eppler, M. J. (2003). Harvesting project knowledge: a review of project learning methods and success factors. International journal of project management, 21(3), 219-228.

Cha, J., Newman, M., \& Winch, G. (2018). Revisiting the project management knowledge framework: Rebalancing the framework to include transformation projects. International Journal of Managing Projects in Business, 11(4), 1026-1043.

Todorović, M. L., Petrović, D. Č., Mihić, M. M., Obradović, V. L., \& Bushuyev, S. D. (2015). Project success analysis framework: A knowledge-based approach in project management. International Journal of Project Management, 33(4), 772-783. 
Ramazani, J., \& Jergeas, G. (2015). Project managers and the journey from good to great: The benefits of investment in project management training and education. International Journal of Project Management, 33(1), 41-52.

Burger, M., \& Zulch, B. (2018). A construction project management knowledge model: The type and Ford, J., \& Harding, N. (2018). Followers in leadership theory: Fiction, fantasy and illusion. Leadership, 14(1), 3-24.level of knowledge required. Acta Structilia, 25(1), 98-125.

Ajmal, M., Helo, P., \& Kekäle, T. (2010). Critical factors for knowledge management in project business. Journal of knowledge management, 14(1), 156-168.

Alavi, M., \& Leidner, D. E. (2001). Knowledge management and knowledge management systems: Conceptual foundations and research issues. MIS quarterly, 107-136.

Chapman, C., \& Ward, S. (1996). Project risk management: processes, techniques and insights. John Wiley.

Fewings, P., \& Henjewele, C. (2019). Construction project management: an integrated approach. Routledge.

Müller, R., Sankaran, S., Drouin, N., Vaagaasar, A. L., Bekker, M. C., \& Jain, K. (2018). A theory framework for balancing vertical and horizontal leadership in projects. International Journal of Project Management, 36(1), 83-94.

Politis, J. D. (2001). The relationship of various leadership styles to knowledge management. Leadership \& Organization Development Journal, 22(8), 354-364.

Ferraris, A., Erhardt, N., \& Bresciani, S. (2019). Ambidextrous work in smart city project alliances: unpacking the role of human resource management systems. The International Journal of Human Resource Management, 30(4), 680-701.

Rubenstein-Montano, B., Liebowitz, J., Buchwalter, J., McCaw, D., Newman, B., Rebeck, K., \& Team, T. K. M. M. (2001). A systems thinking framework for knowledge management. Decision support systems, 31(1), 5-16.

Leseure, M. J., \& Brookes, N. J. (2004). Knowledge management benchmarks for project management. Journal of knowledge management, 8(1), 103-116.

Chapman, C., \& Ward, S. (1996). Project risk management: processes, techniques and insights. John Wiley.

Srivastava, A., Bartol, K. M., \& Locke, E. A. (2006). Empowering leadership in management teams: Effects on knowledge sharing, efficacy, and performance. Academy of management journal, 49(6), 1239-1251.

Donate, M. J., \& de Pablo, J. D. S. (2015). The role of knowledge-oriented leadership in knowledge management practices and innovation. Journal of Business Research, 68(2), 360-370.

Davenport, T. H., De Long, D. W., \& Beers, M. C. (1998). Successful knowledge management projects. Sloan management review, 39(2), 43-57.

Nicolas, R. (2004). Knowledge management impacts on decision making process. Journal of knowledge management, 8(1), 20-31.

Gareis, R., \& Huemann, M. (2000). Project management competences in the project-oriented organization. Gower handbook of project management, 3, 709-721.

Caniëls, M. C., \& Bakens, R. J. (2012). The effects of Project Management Information Systems on decision making in a multi project environment. International journal of project management, 30(2), 162-175. 
Hwang, B. G., \& Ng, W. J. (2013). Project management knowledge and skills for green construction: Overcoming challenges. International Journal of Project Management, 31(2), 272284.

Fischer, G., \& Otswald, J. (2001). Knowledge management: problems, promises, realities, and challenges. IEEE Intelligent systems, 16(1), 60-72.

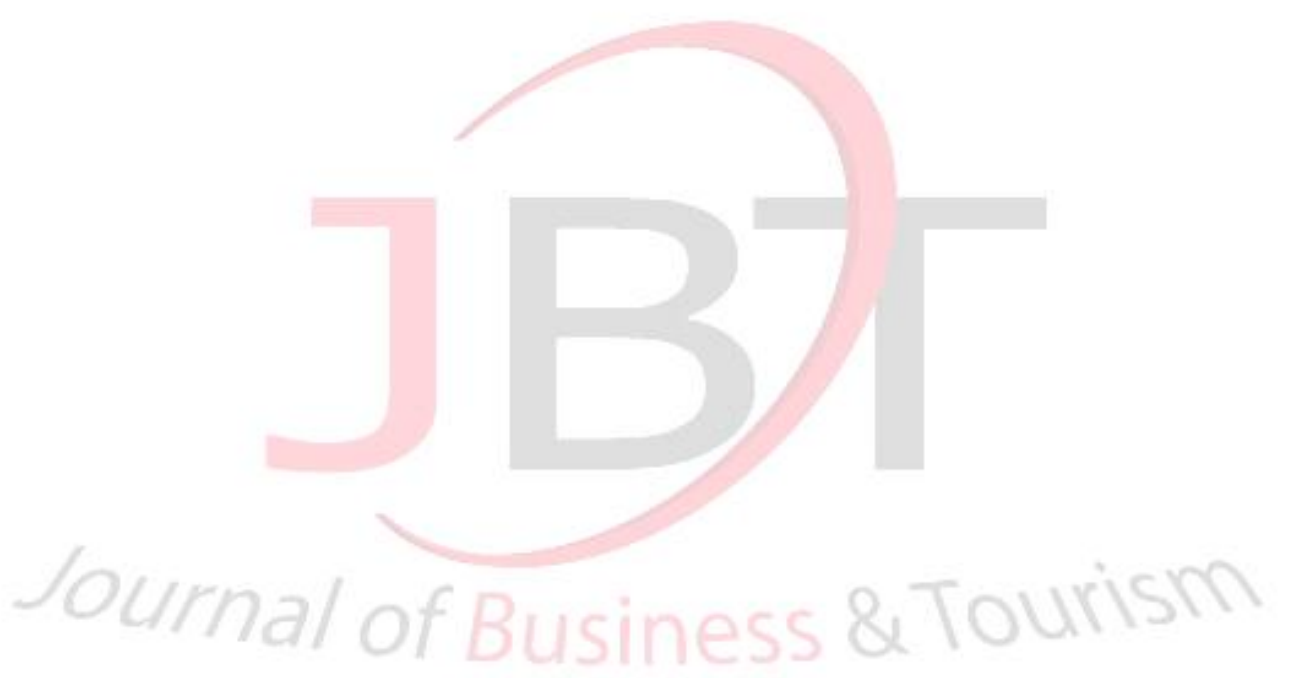

